\title{
REVIEW \\ Bioconversion of Biomass: A Case Study of Ligno-cellulosics Bioconversions in Solid State Fermentation
}

\author{
Ashok Pandey ${ }^{1 *}$ and Carlos R. Soccol ${ }^{2}$ \\ ${ }^{1}$ Biotechnology Division, Regional Research Laboratory, CSIR, Trivandrum-695 019, India; ${ }^{2}$ Laboratorio de \\ Processos Biotecnologicos, Universidade Federal do Parana, CEP81531-970 Curitiba-PR, Brazil, *Currently at 2.
}

\begin{abstract}
Lignocellulosic residues obtained from crops cultivation form useful sources to be used as substrate for bioconversion processes. Sugarcane bagasse, which is a complex substrate obtained from the processing of sugar cane, is an important biomass among such sources. Due to its abundant availability, it can serve as an ideal substrate for microbial processes for the production of value added products. This paper reviews recent developments on biological processes developed on production of various products in solid state fermentation using sugarcane bagasse as the substrate and describes production of protein enriched feed, enzymes, amino acid, organic acids and compounds of pharmaceutical importance, etc. through microbial means.
\end{abstract}

Keywords: Ligno-cellulosics, sugarcane bagasse, bioconversion, solid state fermentation

\section{INTRODUCTION}

\subsection{Sugar Cane}

Sugar cane is a crop being cultivated in countries with a moderate tropical climate. It requires an average rainfall, fertile soil and good sunshine for high productivity. A number of countries in the world produce sugar cane and most of the crop is used for the production of sugar. India and Brazil are among the countries having largest land area under this crop. As such, sugar factories are not the only outlet for sugarcane (especially in India) as conversion of sugar cane into other type of sweetening products, like jaggery and khand is relatively common in villages.

In India, approximately 3500,000-hectare land cover is estimated to be under sugar cane.
Although the average yields of about 65 tonnes per hectare have been generally obtained, yields as high as 90-105 tonnes per hectare are achieved in certain areas of the country, which are as good as the best yields in the world (these values are similar to those of Australian production which is considered highest in the world). The quality of sugar cane cultivated in India is considered fairly good which contains about $12.5 \%$ sugar, although there are varieties cultivated in Western part of the country which contain $13.5 \%$ sugar. There has been a gradual and constant increase in sugar production in the country. With 403 functional sugar factories (against the 503 as licensed) in 1991-92, the sugar production touched a peak of 132.77 tonnes against 85.02 tonnes in $1986-87$ and it is expected that at the end of $9^{\text {th }}$ five-year plan in 1999-2000, it would reach 171.19 tonnes as against 134.13 tonnes in 1994-95.

\footnotetext{
Author for correspondence
} 
During the production of sugar from sugarcane, a number of by-products are produced. Sugarcane bagasse and molasses are the major ones among these.

\subsection{Sugar Cane Bagasse}

Cellulose, the major constituent of all plant materials, forms about half to one-third of the plant tissues and is constantly replenished by photosynthesis. One of the largest cellulosic agro-industrial by-products is sugar cane bagasse, a fibrous residue of cane-stalks left over after the crushing and extraction of cane juice from sugar cane. It is a ligno-cellulosic waste (by-product) of sugar industry, which consists of approximately $50 \%$ cellulose and $25 \%$ each of hemicellulose and lignin. Sugar cane bagasse (or, bagasse as it is generally called) is almost completely used by the sugar factories themselves as fuel for the boilers. Chemically, bagasse contains about 50\% $\alpha$-cellulose, $30 \%$ pentosans and $2.4 \%$ ash. Thus, bagasse offers numerous advantages in comparison to other crop residues (e.g. rice straw and wheat straw which have 17.5 and $11.0 \%$, respectively ash) for usage in bioconversion processes using microbial cultures. Also, in comparison to other agricultural residues, bagasse can be considered as a rich solar energy reservoir due to its high yields (about 80 tonnes per hectare in comparison to about 1,2 and 20 tonnes per hectare for wheat, grass and tree, respectively) and annual regeneration capacity.

\section{SOLID STATE FERMENTATION}

Solid state fermentation (SSF) can be defined as the fermentation process in the absence or nearabsence of free water in the substrate (Aidoo et al. 1982, Hesseltine 1977, Pandey 1992, 1994, Nigam \& Singh 1994). However, there must be enough moisture present in the substrate to support the growth of micro-organisms. There has been wide-spread resurgent of SSF all over the world due to several advantages it offers, mainly on engineering aspects. SSF has successfully been carried out using a number of ligno-cellulosic residues and bagasse is no exception to that.

\section{MICROBES FOR SSF}

As is evident from Table 1, although there are reports on cultivation of bacteria, yeast as well as fungi on bagasse, filamentous fungi have most widely been studied. Valino et al. (1997) used strains of Acinetobacter calcoaceticus and Cephalosporium sp.for studying interactions between microbiote of sugar cane bagasse. The results showed that a better adaptation of bagasse microbiote in solid fermentation, being able to more efficiently overcome any harmful effect compared to the mixture of bacteria and fungi each one separately. A strain of Aspergillus niger was used for biomass estimation on real and model supports (amberlite IRA-900 and bagasse) in SSF (Cordova-Lopez et al.1996).

Zadrazil and Puniya (1995) employed white-rot fungus strains to study the effect of particle size of bagasse in SSF for the production of animal feed with a view to enhancing the nutritive value of the bagasse. They used Pleurotus sp. P7 and $\mathrm{P} 1$, P. eryngii, Agrocybe aegarita A1, and Kuehneromyces mutabilis. The $P$. eryngii improved the digestibility of all the four experimental fractions of the bagasse. Importance of particle size in fungal SSF has also been emphasised by Pandey (1991 a). Gupte and Madamwar (1997 a, b) carried out coculturing of A. ellipticus and A. fumigatus for the production of cellulolytic enzymes. Cellulases and $\beta$-glucosidase were also produced by a strain of A. niger (Ray et al. 1993). Machado et al. (1996) screened 44 basidiomycete strains for their ability to produce ligninolytic enzymes. Among the tested strains, 12 and 7 failed to produce detectable peroxidases and phenoloxidases, respectively. Eleven showed good production, and belonged to the genera Lentinus, Melanoporia, Peniophora, Tramets, Trichaptum and Trogia.

There are other studies also on co-culturing of fungal strains in SSF using bagasse. For 
example, Gutierrez-Correa and Tengerdy (1997, 1998) and Duenas et al. (1995) used strains of Trichoderma reesei and A. niger or A. phoenicis for SSF of bagasse for the production of enzymes. Rodriguez-Vazquez et al. (1992) reported co-culturing of Cellulomonas flavigena and Xanthomonas $\mathrm{sp}$. for the production of single-cell protein (SCP) using bagasse as substrate.

Sharma et al. (1991) used strains of T. viride, Penicillium chrysogenum and Fusarium oxysporum for enzyme production from bagasse. $P$. chrysogenum appeared best among these for cellulase production. Pal et al. (1995) cultivated the mushroom Flammulina velutipes and whiterot fungus Trametes versicolor separately on bagasse for the production of enzymes. Soccol et al. (1994) used Rhizopus oryzae NRRL 395 for solid culturing on bagasse for lactic acid production. Two strains of Streptomyces sp. were used for the protein enrichment of bagasse (Iyo \& Antai 1991). Several other microbial cultures like Chaetomium cellulolyticum (Bravo et al. 1994) and basidiomycetes strains (Nigam 1990, Nigam et al. 1987) were also used for protein enrichment of bagasse.

As generally bacteria require high water activity, they have not been regarded suitable microorganisms for SSF of ligno-cellulosics. In a significant study, however, a bacterial strain of Brevibacterium sp. was shown to grow and produce amino acid in SSF of bagasse (Nampoothiri \& Pandey 1996) in which bagasse was used as inert substrate. Christen et al. (1993) used bagasse as inert support for monitoring the growth of Candida utilis in SSF. Tosmani et al. (1997) cultivated a strain of Gibberella fujikuroi for production of gibberllic acid in SSF of bagasse and Claviceps purpurea was grown on bagasse in SSF for the production of ergot alkaloids (Harnandez et al. 1993).

\section{BIOCONVERSION PROCESSES}

In recent years, there have been a number of reports on the application of sugar cane bagasse as substrate for the production of various products by microbial bioconversions. For the sake of clarity and convenience, we will classify the processes in two categories, one, in which bagasse has been used as the substrate (carbon source) itself while the other, in which it has been used as inert carrier (inert substrate).

\subsection{Processes Involving Bagasse as Solid Substrate (Carbon Source)}

Bagasse has most commonly been used for the production as protein enriched animal feed by solid state fermentation, employing yeast and fungi. A number of reports have appeared on production of animal feed in recent years (cf. table 2). Nigam (1990) and Nigam et al. (1987) investigated solid state fermentation of bagasse for animal feed production using basidiomycetes. $\mathrm{C} / \mathrm{N}$ ratio and initial moisture were critical factors. Zadrazil and Puniya (1995) differentiated bagasse into four fractions of particle size (>1mm, 1-3 mm, 3-5 mm and 5-10 $\mathrm{mm}$ ) with a view to enhancing its nutritive value as animal feed. They found a varying degree of degradation by white-rot fungi and also variation in in vitro rumen digestions. It was concluded that the mechanical separation of a substrate into different particle size could be useful if it was utilized as a substrate to be fermented by filamentous fungi to produce animal feed. Puniya et al. (1996) subjected bagasse to SSF using a strain of $P$. sajor-caju in a closed system, with the aim of optimizing the gaseous atmosphere and developing a cost-effective and simple technology for animal feed production. They found that the application of gases during SSF without disrupting mycelial growth and substrate content was the key to the suitability of this technology. Bravo et al. (1994) treated bagasse with water- or alkali- at threeliquid/solid ratio before using it as substrate for microbial protein production. The treatment significantly enhanced fungul growth compared to non-treated bagasse. Rodriguez-Vazguez et al. (1992) also treated bagasse (pith) with a solution of sodium hydroxide in such a low volume that no free liquid was present. They referred it as dry pre-treatment and compared with a wet pre- 
treatment. Maximum digestibility with dry and wet pre-treated bagasse was 75 and $71 \%$, respectively. Biomass production was also higher in dry process. Iyo and Antai (1991) achieved $21 \%$ crude protein in bagasse after 12 weeks cultivation of a fungal strain of Streptomyces, which resulted $45 \%$ depletion of lignocelluloses.

A patent was obtained by Hayashibara Biochem. Res. (Iritani et al. 1995) on the application of bagasse, softened with alkali treatment, for feedstuff, fertilizer, and sweetener by cultivating Enterococcus faecium in SSF. Chaudhary et al. (1994) also reported feedstuff production from bagasse using two strains of Pleurotus sp.

Amongst the various enzymes produced in SSF of bagasse, cellulases have most extensively been studied. It is well established that the hydrolysis of the lignocellulosic residues using enzyme largely depends upon the cost of the production of cellulases. Application of bagasse in SSF for this purpose appears attractive. Sharma et al. (1991, 1995) reported production of cellulases from different fungal strains. Significant FPD activity was noted from $P$. chrysogenum, which, apart from the enzyme, also showed high levels of reducing sugars (glucose and xylose). They suggested an integral process for the production of ethanol, furfural, fermentable sugars and biogas from bagasse. Roussos et al. (1992) used a mixture of bagasse and wheat bran (4:1) for the production of cellulases. They suggested hydraulic pressing as a good technique to leach out the enzymes from the fermented matter. Modi et al. (1994) reported better yields of cellulase from a strain of Streptomyces sp. HM29 when grown on bagasse in comparison to rice straw, rye straw and corncobs. Yields were comparable with those obtained from rice bran but lower than those from wheat straw, wheat bran and newspaper.

Often, cultivation of two different strains as mixed culture and pre-treatment of bagasse showed desirable impact on fermentation. Gupte and Madamwar (1997 a, b) reported that production of cellulolytic enzymes under SSF by co-culturing of two fungal strains showed improved hydrolytic and $\beta$-glucosidase activities as compared to the occasions when they were used separately. Alkali pre-treatment further improved the enzyme production (Gupte \& Madamwar 1994). Similarly, Gutierrez-Correa and Tengerdy (1997) also reported higher cellulase productivity in co-culturing of a basidiomycete strain with another filamentous fungi. A mutual synergism was observed between the parent strain (of T. reesei LM-UC4) and the A. phoenicis QM 329, resulting in enhanced combined biomass production and corresponding increase in cellulase, endoglucanase and $\beta$-glucosidase activities. When coculturing was carried out using a mutant strain of $T$. reesei LM-UC4E1, such synergism was absent, suggesting that in the hypermutation the ability for co-operative interaction with other microbes was lost. Treatment of bagasse with ammonia $(80 \%, \mathrm{w} / \mathrm{w}$ moisture content) resulted higher enzyme productivity (Duenas et al. 1995).

An extensive study was carried out by $\mathrm{Pal}$ et al. (1995) on SSF of bagasse using a strain of mushroom fungus and another of white-rot fungus separately for 40 days. $T$. versicolor produced laccase and manganese-peroxidase activities, showing a simultaneous degradation of lignin and holocellulose. However, only phenol-oxidase activity was found with $F$. velutipes. A preferential degradation of lignin was detected in this case, which exhibited a greater reduction in the ratio of weight loss to lignin loss than the other culture.

Xylanase was another enzyme produced under SSF of bagasse. Jain (1995) used a thermophilic fungus for the production of extra-cellular xylanase on various agro-residues, including bagasse. Fungus grew well on untreated bagasse and enzyme titres were lower when fungus was grown on treated (alkali or acid chlorite treatment) bagasse. Acetyl esterase was produced concurrently, maximal activity being with bagasse in comparison to other substrates. Gutierrez-Correa and Tengerdy (1998) also performed xylanase production in SSF using bagasse. They co-cultured $T$. reesei and A. niger 
Table 1. Micro-organisms employed in SSF of bagasse

\begin{tabular}{|c|c|}
\hline Micro-organism & References \\
\hline Acinetbacter calcoaceticus & Valino et al. (1997) \\
\hline Agrocybe aegarita A1 & Zadrazil \& Punia (1993) \\
\hline Aspergillus ellipticus & Gupte \& Madamwar (1997 a) \\
\hline A. fumigatus & Gupte \& Madamwar (1997 a, b) \\
\hline \multirow[t]{3}{*}{ A. niger } & Acuna-Arguelles et al. (1994) \\
\hline & Cordova-Lopez et al. (1996) \\
\hline & $\begin{array}{l}\text { Huerta et al. (1994), Ray et al.(1993), } \\
\text { Solis-Pereyra et al. (1996) }\end{array}$ \\
\hline A. ochraceus & Biswas et al. (1988) \\
\hline \multirow[t]{2}{*}{ A. phoenicis } & Gutierrez-Correa \& Tengerdy (1998) \\
\hline & Duenas et al. (1995) \\
\hline Brevibacterium sp. & Nampoothiri \& Pandey (1996) \\
\hline Candida utilis & Christen et al. (1993) \\
\hline Cellulomonas flavigena & Rodriguez-Vazquez et al. (1992) \\
\hline Cephalosporium sp. & Valino et al. (1997) \\
\hline Ceratocystis fimbriata & Christen et al. $(1994,1997)$ \\
\hline Chaetomium cellulolyticum & Bravo et al. (1994) \\
\hline Claviceps purpurea & Harnandez et al. (1993) \\
\hline Enterococcus faecium & Iritani et al. (1995) \\
\hline Flammulina velutipes & Pal et al. (1995) \\
\hline Fusarium oxysporum & Sharma et al. (1991) \\
\hline Gibberella fujikuroi & Tosmani et al. (1997) \\
\hline Kuehneromyces mutabilis & Zadrazil \& Punia (1995) \\
\hline Melanocarpus albomyces IIS-68 & Jain (1995) \\
\hline Monascus purpureus & Chiu \& Chan (1992) \\
\hline \multirow[t]{2}{*}{ Penicillium chrysogenum } & Barrios-Gonzalez et al. (1993) \\
\hline & Sharma et al. (1991) \\
\hline Pleurotus sp. P7 & Zadrazil \& Puniya (1995) \\
\hline P. cornucopiae & Chaudhary et al. (1994) \\
\hline P. eryngii & Zadrazil \& Puniya (1995) \\
\hline P. florida & Chaudhary et al. (1994) \\
\hline P. sajor-caju & Puniya et al. (1996) \\
\hline \multirow{2}{*}{ Polyporus sp. } & Nigam (1990), \\
\hline & Nigam et al. (1987) \\
\hline Rhizopus oryzae & Soccol et al. (1994) \\
\hline Schwanniomyces castellii & Saucedo-Castaneda et al. (1992) \\
\hline Streptomyces sp. & Iyo \& Antai 1991, Modi et al. (1994) \\
\hline Trametes versicolor & Pal et al. (1995) \\
\hline Trichoderma harzianum & Roussos et al. (1992) \\
\hline T. reesei & $\begin{array}{l}\text { Gutierrez-Correa \& Tengerdy (1997), } \\
\text { Gutierrez-Correa \& Tengerdy (1998), } \\
\text { Duenas } \text { et al. (1995) }\end{array}$ \\
\hline T. viride & Sharma et al. (1991) \\
\hline Xanthomonas sp. & Roudriguez-Vazquez et al. (1992) \\
\hline
\end{tabular}


Table 2. Products of SSF of bagasse (used as carbon/energy source)

\begin{tabular}{|c|c|}
\hline Products & References \\
\hline Protein enriched feed & $\begin{array}{l}\text { Nigam (1990), Nigam et al. (1987), } \\
\text { Zadrazil \& Puniya (1995), Bravo et al. } \\
\text { (1994), Iyo \& Antai (1991), Rodriguez-Vazguez } \\
\text { et al. (1992), Puniya et al. (1996), Iritani et al. } \\
\text { (1995), Chaudhary et al. (1994), }\end{array}$ \\
\hline Cellulases & $\begin{array}{l}\text { Sharma et al. }(1991,1995), \text { Ray et al. }(1993) \\
\text { Gupte \& Madamwar }(1994,1997 \text { a, b) Gutierrez- } \\
\text { Correa \& Tengerdy }(1997,1998), \text { Duenas et al. } \\
\text { (1995), Roussos et al. (1992) }\end{array}$ \\
\hline Laccase & Pal et al. (1995), Machado et al. (1996) \\
\hline Ligninase & $\begin{array}{l}\text { Nigam et al. (1987), } \\
\text { Machado et al. (1996) }\end{array}$ \\
\hline Mn-peroxidase & Pal et al. (1995), Machado et al. (1996) \\
\hline Phenol oxidase & Pal et al. (1995), Machado et al. (1996) \\
\hline Xylanase & $\begin{array}{l}\text { Jain (1995), Gutierrez-Correa \& Tengerdy (1998), } \\
\text { Biswas et al. (1988) }\end{array}$ \\
\hline Aroma production & Christen et al. (1994) \\
\hline Acetyl esterase & Jain (1995) \\
\hline Gibberllic acid & Tosmani et al. (1997) \\
\hline Fruity aroma & Christen et al. (1997) \\
\hline Pigments & Chiu \& Chan (1992) \\
\hline Composting/Ensiling & Baca et al. (1993), Roussos et al. (1992) \\
\hline
\end{tabular}

Table 3. Products of SSF of bagasse (used as inert carrier)

\begin{tabular}{ll}
\hline Products & \multicolumn{1}{c}{ References } \\
\hline Glutamic acid & Nampoothiri \& Pandey (1996) \\
Ergot alkaloids & Hernandez et al. (1993) \\
Lactic acid & Soccol et al. $($ 1994) \\
Citric acid & Lakshminarayana et al. (1975), \\
& Manonmani \& Sreekantiah (19987) \\
Pectinases & Solis-Pereyra et al. (1996), Huerta et al. \\
& (1994), Acuna-Arguelles et al. (1994) \\
Penicillin & Barrios-Gonzalez et al. (1993) \\
\hline
\end{tabular}


or A. phoenicis and achieved high xylanase titres $(2,600-2,800 \mathrm{IU} / \mathrm{g}$ dry wt).

The spectra of SSF of bagasse increased further with the report appearing on production of other products, like gibberllic acid. Tosmani et al. (1997) compared gibberllic acid production in liquid fermentation with SSF. Different SSF systems were used. SSF of bagasse showed excellent fungal growth but presented extraction problem.

\subsection{Processes Involving Bagasse as Solid Inert Substrate (Inert Carrier)}

SSF carried out on inert support materials, which differs from the process of microbial growth on or in solid particles floating in a liquid medium has been regarded as one of the future development of SSF systems (Aidoo et al. 1982, Pandey 1991b, 1992). The use of solid inert material impregnated with suitable liquid media would provide homogenous aerobic conditions throughout the bioreactor and the purity of the product would also be relatively high.

\subsubsection{Processing Involving Bagasse as Solid Inert Substrate for Products}

In a unique study, the first of its type, Nampoothiri and Pandey (1996) reported production of L-glutamic acid in which bagasse was impregnated with a medium containing glucose, urea, mineral salts and vitamins. Maximum yields (80-mg glutamic acid/g dry bagasse) were obtained when bagasse of mixed particle size was fermented with $85-90 \%$ moisture and $10 \%$ glucose. Yet, in a significant finding, Hernandez et al. (1993) reported production of ergot alkaloids from a fungus culture grown on bagasse, impregnated with a liquid medium. They used a total of sixteen different combinations of liquid media and concluded that there existed the possibilities of achieving tailor-made spectra of ergot alkaloids by changing the liquid nutrient media composition used for impregnation. BarriosGonzalez et al. (1993) studied the effect of particle size, packing density and agitation on penicillin production in SSF using bagasse as inert substrate. The use of a large particle size (14-mm) bagasse increased penicillin production by $37 \%$. Christen et al. (1997) reported production of fruity aroma on bagasse when it was fermented with a nutritive medium containing glucose $(200 \mathrm{~g} / \mathrm{L})$. Twenty-four compounds were separated and twenty of them were identified from the headspace analysis of the fermenter by GC. Aroma production was dependent on the growth and the maximum aroma intensity was detected at about time of the maximum respirometric activity.

Soccol et al. (1994) evaluated potential of bagasse to be used as inert substrate, impregnated with a liquid medium containing glucose and calcium carbonate, for lactic acid production from a strain of Rhizopus oryzae NRRL 395. Keeping glucose level at 120 and $180 \mathrm{~g} / \mathrm{L}$ for liquid and solid state fermentation, an yield of 93.8 and $137.0 \mathrm{~g} / \mathrm{L}$ of $\mathrm{L}(+)$-lactic acid was obtained, respectively. The productivity was 1.38 and $1.43 \mathrm{~g} / \mathrm{l} / \mathrm{h}$ in liquid and solid fermentation, respectively. Citric acid was another organic acid, which was produced in SSF using bagasse as inert carrier (Laxminarayana et al., 1975). Manonmani and Sreekantiah (1987) conducted citric acid production using enzymatic hydrolyzate of alkali treated bagasse by SSF.

Pectinases were produced in SSF using bagasse impregnated with high glucose concentration (Solis-Pereyra et al. 1996). They used packed bed column fermenter. In a similar study, Huerta et al. (1994) concluded that SSF carried out on inert substrates (they referred it as adsorbed substrate fermentation technique) not only allowed the design of culture medium to produce important metabolites, but also the study of fungal metabolism in artificially controlled SSF processes. Acuna-Argulles et al. (1994) studied the effect of water activity on pectinases production using bagasse impregnated with a medium containing pectin and sucrose. Ethylene glycol, sorbitol and glycerol were used as water activity depressors. Results indicated that 
although polygalacturonase production decreased at low $a_{w}$ values, this activity was present at $\mathrm{a}_{\mathrm{w}}$ values as low as 0.90 . The specific activity increased up to 4.5 -fold by reducing $\mathrm{a}_{\mathrm{w}}$ from 0.98 to 0.9 .

Chiu and Chan (1992) described production of pigments using bagasse in roller bottle cultures of Monascus purpurea. Fungus was cultivated in wet bagasse containing PGY medium with corn oil in SSF when it produced red and yellow pigments.

\subsubsection{Processing Involving Bagasse as Solid Inert Substrate for Growth/Model Studies}

Solid substrates of inert nature offer several advantages on measurements of growth in SSF and made it possible to study growth kinetics in SSF. Bagasse has been commonly employed for this purpose. Christen et al. (1993) successfully monitored the growth of Candida utilis in a bagasse medium in SSF. Auria et al. (1993) conducted a study on the influence of mould growth on the pressure-drop in aerated SSF using bagasse and wheat bran. They proposed the measurement of pressure-drop (DELTAP) across an aerated fermentation bed as an alternative on-line sensor for the qualitative and, in some cases, quantitative, macroscopic changes in static SSF. Oriol et al. $(1987,1988)$ also used bagasse impregnated with a liquid growth medium for studying growth kinetics of $A$. niger.

In an attempt to estimate fungal biomass in SSF, Cordova-Lopez et al. (1996) carried out direct hydrolysis of fungal mycelium grown on bagasse in SSF, followed by the analysis of soluble protein by the dye binding method. Hydrolysis with phosphoric acid for 7 minutes allowed maximum protein extraction and there was no colour interference by the medium components.

Valino et al. (1997) carried out an experiment with the objective of studying the interactions between the microbiotes of bagasse and fungal and bacterial strains being cultivated on it in SSF. A factorial arrangement with replications was used. The results showed a better adaptation of bagasse microbiote in SSF, being able to more efficiently overcome any undesirable effect compared to the mixture of bacteria and fungi, each one separately.

\section{RESUMO}

Resíduos celulósicos obtidos a partir do cultivo de plantas podem ser utilizados como substratos nos processos de bioconversão. Bagaço de cana é um importante substrato e fonte de biomassa obtido a partir do processamento da cana de açucar. Em razão da sua produção em grandes volumes o mesmo pode ser utilizado como substrato ideal em processos microbianos para obtenção de produtos de elevado valor comercial. Esse trabalho de revisão apresenta os recentes desenvolvimentos em processos biológicos utilizando a técnica da fermentação no estado sólido na obtenção de enzimas, aminoácidos, ácidos orgânicos e componentes farmacêuticos de interesse industrial.

\section{REFERENCES}

Acuna-Arguelles, M, Gutierrez-Rojas, M, Viniegra-Gonzalez, G, \& Favela-Torres, E. (1994) Effect of water activity on exopectinase production by Aspergillus niger $\mathrm{CH} 4$ on solid state fermentation. Biotechnol Letts, 16, 23-28

Aidoo, KE, Hendry R \& Wood, JB. (1982) Adv Appl Microbiol, 28, 201-237

Auria, R, Morales, M, Villegas, E, \& Revah, S. (1993) Influence of mold growth on the pressure-drop in aerated solid state fermenters. Biotechnol Bioeng,41, 1007-1013

Baca, MT, Steban, E, Almendros, G \& Sanchezraya, AJ. (1993) Changes in gas phase of compost during solid state fermentation of sugar cane bagasse. Biores Technol, 44, 5-8

Barrios-Gonzalez, J, Gonzalez, H, \& Mejia, A. (1993) Effect of particle size, packing density and agitation on penicillin production in solid 
state fermentation. Biotechnol Adv, 11, 539547

Biswas, SR, Mishra, AK \& Nanda, G. (1988) Xylanase and beta glucosidase production by Aspergillus ochraceus during growth on lignocelluloses. Biotechnol Bioeng, 31, 613616

Bravo, O, Ferrer, A, Aiello, C, Ledesma, A \& Davila, M. (1994) Growth of Chaetomium cellulolyticum in solid state fermentation of sugar cane bagasse treated with water and alkali at several liquid/solid ratios. Biotechnol Letts, 16, 865-870

Chaudhary, LC, Singh, R, \& Kamra, DN. (1994) Biodelignification of sugar cane bagasse by Pleurotus florida and Pleurotus cornucopiae. Indian J Microbiol, 34, 55-57

Chiu, SW \& Chan, SM. (1992) Production of pigments by Monascus purpurea using sugar cane bagasse in roller bottle cultures.World $J$ Microbiol Biotechnol, 8, 68-70

Christen, P, Auria, R, Vega, C, Villegas, E, \& Revah, S. (1993) Growth of Candida utilis in solid state fermentation. Biotechnol Adv, 11, 549-557

Christen, P, Meza, JC, \& Revah, S. (1997) Fruity aroma production in solid state fermentation by Ceratocystis fimbriata: influence of the substrate type and the presence of precursors. Mycol Res, 101, 911-919

Christen, P, Villegas, E, \& Revah, S. (1994) Growth and aroma production by Ceratocystis fimbriata in various fermentation media. Biotechnol Letts, 16, 1183-1188

Cordova-Lopez, J, Gutierrez-Rojas, M, Huerta, A, \& Saucedo-Castaneda, G. (1996) Biomass estimation of Aspergillus niger growing on real and model supports in solid state fermenation. Biotechnol Tech, 10, 1-6

Duenas, R, Tengerdy RP, Guierrez-Correa, M. (1995) Cellulase production by mixed fungi in solid sibstrate fermentation of bagasse. World J Microbiol biotechnol, 11, 333-337

Gupte, A \& Madamwar, D. (1994) High strength cellulase and beta-glucosidase formation from Aspergillus sp. under solid state fermentation. IN- Solid State Fermentation.
Ed. A. Pandey, Wiley Eastern Publishers, New Delhi, pp. 130-133

Gupte, A \& Madamwar, D. (1997a)Production of cellulolytic enzymes by co-culturing of Aspergillus ellipticus and Aspergillus fumigatus grown on bagasse under solid state fermentation. Appl Biochem Biotechnol, 62, 267-274

Gupte, A \& Madamwar, D. (1997b) Solid state fermentation of ligno-cellulosic wastes for cellulase and beta-glucosidase production by co-culturing of Aspergillus ellipticus and Aspergillus fumigatus. Biotechnol Progress, 13, 166-169

Gutierrez-Correa, M \& Tengerdy RP. (1997) Production of cellulase on sugar cane bagasse by fungal mixed culture solid substrate fermentation. Biotechnol Letts, 19, 665-667

Gutierrez-Correa, M \& Tengerdy RP. (1998) Xylanase production by fungal mixed culture solid state fermentation on sugar cane bagasse. Biotechnol Letts, 20, 45-47

Hernandez, MRT, Lonsane, BK, Raimbault, M \& Roussos, S. (1993) Spectra of ergot alkaloids produced by Claviceps purpurea in solid state system - influence of the composition of liquid medium used for impregnating sugar cane bagasse. Process Biochem, 28, 23-27

Hesseltine, CW. (1977) Solid-state fermentation. Process Biochem, 12, 22-24

Huerta, S, Favela, E, Lopez-Ulibarri, R, Fonseca, A, Viniegra-Gonzalez, G, \& Gutierrez-Rojas, M. (1994) Absorbed substrate fermentation for pectinase production with Aspergillus niger. Biotechnol Tech, 8, 837-842

Iritani, S, Mitsuhashi, M, Chaen, H \& Miyake, T. New alkali treated bagasse used as livestock feed. PN : GB 2285806; 26.07.95

Iyo, AH \& Antai, SP. (1991) Protein enrichment of lignocellulose resulting from the growth of two Streptomyces strains. World J Microbiol Biotechnol, 7, 624-625

Jain, A. (1995) Production of xylanase by thermophilic Melanocarpus albomyces IIS68. Process Biochem, 30, 705-709

Lakshminarayana, K., Chaudhary, K., Ethiraj, S. and Tauro, P. (1975) Biotechnol. Bioeng., 7, 291-293 
Machado, KMG, Silva, WRF \& Bononi, VLR. (1996) Screening of ligninolytic fungi for soil remediation. II-Production of peroxidases and phenol oxidases. Int. Biodeterio. Biodegrd., 37, 130

Manonmani, HK \& Sreekantiah, KR. (1987) Studies on the conversion of cellulase hydrolysate into citric acid by Aspergillus niger. Process Biochem, 22, 92-94

Modi, HA, Patel KC \& Ray, RM. (1994) Solid state fermentation for cellulase production by Streptomyces sp HM-29. IN- Solid State Fermentation. Ed. A. Pandey, Wiley Eastern Publishers, New Delhi, pp. 137-141

Nampoothiri, KM \& Pandey, Ashok. (1996) Solid state fermentation for L-glutamic acid production using Brevibacterium sp. Biotechnol Letts, 18, 199-204

Nigam, P. (1990) Investigation of some factors important for solid state fermentation of sugar cane bagasse for animal feed production. Enz Microb Technol, 12, 808-811

Nigam, P \& Singh, D. (1994) Solid state (substrate) fermentation systems and their applications in biotechnology. J. Basic Microbiol, 34, 405-14

Nigam, P, Pandey, Ashok \& Prabhu, KA. (1987) Cellulase and ligninase production by basidiomycetes in solid state fermentation. Biol wastes, 20, 1-9

Oriol, E, Contreras, R \& Raimbault, M. (1987) Use of microcalorimetry for monitoring the solid state culture of Aspergillus niger. Biotechnol Tech, 1, 79-84

Oriol, E, Schettino, B, Viniegra-Gonzalez, G \& Raimbault, M. (1988) Solid state culture of Aspergillus niger on support. $J$ Ferment Technol, 66, 57-62

Pal, M, Calvo, AM, Terron, MC \& Gonzalez, AE. (1995) Solid state fermentation of sugar cane bagasse with Flammulina velutipes and Trametes versicolor. World J Microbiol Biotechnol, 11, 541-545

Pandey, Ashok. (1991a) Effect of particle size of the substrate on enzyme production in solid state fermentation. Biores. Technol., 37, 169172
Pandey, Ashok. (1991b) Aspects of design of fermenter in solid state fermentation. Process Biochem, 26, 355-361

Pandey, Ashok. (1992) Recent developments in solid state fermentation. Process Biochem, 27, 109-117

Pandey, Ashok. (1994) Solid state fermentation: An ioverview. IN - Solid State Fermentation. Ed. A. Pandey, Wiley Eastern Publishers, New Delhi, pp. 3-10

Puniya, AK, Shah, KG, Hire, SA, Ahire, RN, Rathod, MP \& Mali, RS. (1996) Bioreactor for solid state fermentation of agro-industrial wastes. Indian J. Microbiol, 36, 177-78

Ray, L, Pal, A, Ghosh, AK \& Chattopadhyay, P. (1993) Cellulases and beta-glucosidase from Aspergillus niger and saccharification of some cellulosic wastes. J. Microbial Biotechnol, 8, 85-94

Rodriguez-Vazquez, R, Villanuevaventura, G \& Riosleal, E. (1992) Sugarcane bagasse pith dry pretreatment for single cell protein production. Biores Technol, 39, 17-22

Roussos, S, Raimbault, M, Geoffroy, F, Saucedo-Castaneda, G \& Lonsane, BK. (1992) Efficient leaching of cellulases produced by Trichoderma harzianum in solid state fermentation. Biotechnol Tech, 6, 429432

Roussos, S, Raimbault, M, Saucedo-Castaneda, G \& Lonsane, BK. (1992) Potential of ensiling for efficient management of spent residue from solid state fermentation system. Biotechnol Tech, 6, 87-90

Saucedo-Castaneda, G, Lonsane, BK, Navarro, JM, Roussos, S, \& Raimbault, M. (1992) Control of carbondioxide in exhaust air as a method for equal biomass yields at different bed heights in a column fermenter. Appl Microbiol Biotechnol, 37, 580-582

Sharma, DK, Niwas, S \& Behera, BK. (1991) Solid state fermentation of bagasse for the production of cellulase enzyme from cellulolytic fungi and extent of simultaneous production of reducing sugars in the fermenter. J. Microbial Biotechnol, 6, 7-14 
Sharma, DK, Tiwari, M \& Behera, BK. (1995) Solid state fermentation of new substrates for production of cellulase and other biopolymer hydrolysing enzymes - scientific note. Appl Biochem Biotechnol, 51-52, 495-500

Soccol, CR, Marin, B, Raimbault, M \& Lebeault, JM. (1994) Potential osf solid state fermentation for production of $\mathrm{L}(+)$-lactic acid by Rhizopus oryzae. Appl Biochem Biotechnol, 41, 286-290 (

Solis-Pereyra, S, Favela-Torres, E, GutierrezRojas, M, Roussos, S, Saucedo-Castaneda, G, Gunasekaran, P, \& Viniegra-Gonzalez, G. (1996) World J Microbiol Biotechnol, 12, 257-260

Tosmani, A, Fajardo, C \& Barrios-Gonzalez, J. (1997) Gibberllic acid production using different solid state fermentation systems. World J Microbiol Biotechnol, 13, 203-206
Valino, E, Elias, A, \& Albelo, N. (1997) Interactions between the microbiote of sugar cane bagasse and Cephalosporium sp. and acinetobacter calcoaceticus strains in solid state fermentation. Cuban J Agri Sci, 31, 279285

Zadrazil, F \& Puniya, AK. (1995) Studies on effect of particle size on solid state fermentation of sugar cane bagasse into animal feed using white-rot fungi. Biores Technol, 54, 85-87
Received: October 15, 1998; Revised: October 30, 1998; Accepted: November 17, 1998. 
